\title{
EURO Based Currency Union: Motivation for Muslim Countries' Economic Growth
}

\author{
Mohammad Naveed Ahmed \\ Department of Business Administration \& Tourism Management \\ Yunnan University, Kunming, China \\ E-mail: n.ahmed@ymail.com \\ Kanya Hemman \\ Department of Business Administration \& Tourism Management \\ Yunnan University, Kunming, China \\ E-mail: h.kanya@yahoo.com
}

\begin{abstract}
In economics, a monetary union is a situation where several countries have agreed to share a single currency (also known as a unitary or common currency) among them, for example, the EURO currency. A currency union differs from an economic and monetary union, where it is not just currency but also economic policy that is pooled or coordinated by a region. This paper will look into the EURO currency based currency union to see whether it really improves the member countries economic performance or not, which might be the motivation for Muslim countries to organize a currency union for their growth. To do this research, the economic data are collected from the World Bank Development Indicators database.
\end{abstract}

Keywords: Currency Union, EURO, Gold dinar

\section{Introduction}

Currency union is adoption of a single currency by a bunch of countries. European Union (EU) has recently formed a currency union by adopting a single currency called euro. Dollar inflation is the primary economic motivation and compulsion to seek a European substitute for the dollar. Primary aim under European Monetary Union (EMU) was to guarantee a price stability through monetary policy conducted by independent European central bank (ECB) using a single European currency. Most European countries confronted serious economic difficulties after World War II. Demand for import goods from the dollar exceeded the limited supply of export beyond their overall balance of payment capacity. Therefore, all European countries struggled to earn surpluses in gold, dollar or any currency convertible to dollar, without success. So it was realized that a joint European effort is essential to overcome balance of payments difficulties of individual European countries. The realization led to formation of the European Payment Unions (EPU) by 18 countries on 1 July 1950. The EPU provided some relief as all bilateral deficits surpluses among the European countries were netted out into one overall net monthly position with EPU. The EUA that became the European Currency Unit (ECU) later was defined as gold content of one dollar the international monetary standard at the time.

Advantages of a currency union for member countries are many including efficiency, transparency, stability and reduction in currency speculation. A common currency brings efficiency by eliminating transactions costs resulting from money changing. In a currency union there is no need to calculate prices in different currencies and to hold cash balances in different currencies. Currency transaction costs on intra-union trade are eliminated as companies save costs due to exchange rate spreads, hedging, and maintenance of their exchange rate departments. Besides, it reduces information costs, because with common currency it is easier to compare prices within member countries and there is no need to collect information about present exchange rates, future exchange rates and exchange market regulations in the member countries. A common currency also eliminates the risks connected with nominal exchange rate changes and exchange controls. Thus a common currency has a potential to improve the international allocation of financial capital. The flexible exchange rate regime, assumed since 1971, has increased importance of currencies as financial assets, rather than as a medium of exchange. So maintaining a separate currency has become more costly because currency is subjected to unpredictable 
speculative attacks irrespective of the strength of economics fundamentals in a country. In fact the cost of maintaining a separate currency will be eliminated under a currency union. A single stable money is better than multiple currencies, even as a medium of exchange. Furthermore, functioning of economic system would be more transparent because it is much easier to compare the prices when all prices are quoted in the same currency. For instance, it becomes more difficult for automobile producer to charge different prices when a single currency allows consumers to readily compare prices across countries. Similarly, banks can not practice unreasonable rates on deposits and loans as elimination of currency risk due to common currency encourages savers and investor to seek competitive rates elsewhere.

Seems Euro currency works for European countries member, it was suggested for Muslim country to adopt Gold Dinar as Muslim currency union. Introduction of GD as a parallel currency in interested Muslim countries is recommended to mark a beginning toward formulation of a GD currency union. Because a GD currency union of Muslim countries would provide stable money serving as excellent medium of exchange that would minimize speculation, promote trade and dilute socioeconomic evils. That is the basic reason for search of a stable currency to protect asset from damages inflicted by currency speculations and loss of liquidity value due to volatility in exchange rates.

\section{Literature Review}

This paper aims to explore the relation between having a currency union and regional growth, specifically in the Euro-zone. According to the European Commission (1996, p.16), "its task is to guarantee price stability". This is the precondition to achieve all the abovementioned advantages of forming a currency union. This is because "a stable currency is regarded as the best guarantee for protecting the real value of financial assets, real estate and the social welfare system" (Expert Group on the Changeover to the Single Currency, 1995, p.4).

However, the world has seen the volatility of the prices, after its departure from the gold systems, in which the "flooding of dollar reserves by USA made it absolutely impossible for the fixed exchange rates to function satisfactorily" (Triffin, 1980, p.46). In response to this, there is a need to create a currency union to provide a "shelter" for member states. This is clearly expressed by Raymond (1995), the Director-General of the European Monetary Institutes:

"Of course, sheltering Europe from drawbacks of exchange rate volatility is only one of the aims of the Economic and Monetary Union. Another aim is to create in Europe, an area with a stable currency, because a stable currency certainly means sustainable low inflation in the long run"

The history of the European Union can be traced back to post-World War II. Determined to rebuild the war-torn nations and to prevent future conflicts, six Western European countries formed the European Coal and Steel Community (ECSC) in 1952.

Leaders had realized that the best way to ensure a lasting peace among European nations was to unite them both economically and politically. As a next step, the same six countries, i.e. Belgium, Germany, France, Italy, Luxembourg, and the Netherlands established the European Economic Community (EEC) and the European Atomic Energy Community (EURATOM) through the Treaty of Rome in 1958. A decade later, the six founder member states had achieved most of the aims described in the Treaty, and as a result their economies had grown increasingly intertwined. The EEC had become an important trading bloc on the international level as well. Soon, the Community Concluded that economic and monetary union was to be made a formal goal.

Several plans were submitted in 1969 and 1970, describing how the European community (EC), as it was now also called could potentially move toward a monetary union. They differed in their views on economic cooperation and coordination, such as the fixing of exchange rates or the freedom of capital mobility.

On January 1, 1999, Stage Three of the EMU officially began. The conversion rates of the currencies of the 11 member states meeting the convergence criteria (Austria, Belgium, Finland, France, Germany, Ireland, Italy, Luxembourg, the Netherlands, Portugal, and Spain) were irrevocably fixed as in table below.

Insert table 1 here

All these nations accepted the euro as their single currency. The European Central Bank was delegated all responsibility for conducting the now single monetary policy in the euro area. A transitional period was implemented. From the start of 1999 until December 31, 2001, all agents denominating claims and liabilities or carrying out cashless transactions were permitted to use either the euro or the national currencies. In 2001, the number of member states participating in the euro grew to 12 with the addition of Greece. Finally, on January 1 , 
2002, euro banknotes and coins were put into circulation. As of the end of February 2002, the euro is the sole legal tender of the member states.

\section{The Welfare effect of Common Currencies}

\subsection{International Risk Sharing}

It is a well-known result of general-equilibrium theory that if asset markets are complete, risk averse individuals can and will fully insure against consumption fluctuations across states. In an environment that has neutral money and multiple currencies, this implies that the choice of an exchange rate regime will not have any impact on social welfare (Helpman 1981, Kareken and Wallace 1982, Lucas 1982). In practice, however, asset markets will be incomplete and risk cannot be completely hedged, in particular at the more aggregate level, and so the exchange rate regime may indeed matter. There are two approaches to considering the impact of the exchange rate in the context of region-specific shocks hitting the economy. First, flexible exchange rates may substitute for other adjustment mechanisms (like price and wage adjustments or central fiscal transfers) if the latter are not available. This important insight, by Mundell (1961), underlies most of what has become known as the Theory of Optimum Currency Areas.

What is perhaps less known is that, several years later, Mundell presented a new view of common currencies as a means of smoothing shocks by better reserve pooling and portfolio diversification.

According to this approach, which has recently been "rediscovered" by McKinnon (2000), countries sharing a single currency can mitigate the effects of asymmetric shocks among themselves by diversifying their income source and adjusting their wealth portfolio.

The international diversification of income source can operate through income insurance when residents of a country hold claims to dividends, interests, and rental revenue in other countries. Such ex-ante insurance allows the smoothing of both temporary and permanent shocks as long as output is imperfectly correlated.

A country's residents can adjust their wealth portfolio in response to income fluctuations by buying and selling assets and borrowing and lending on international credit markets. Such ex-post adjustment allows the smoothing of transitory shocks (Mongelli 2002, 13, and references therein).

\subsection{Financial Market Integration and its Impact on Growth}

By eliminating exchange risk and increasing transparency, EMU is thought to contribute to ongoing financial market integration in Europe. Of course, this process is also driven by other important factors, like the Internal Market Program and financial reforms at the national level. Financial integration has been assigned a high priority on the EU economic reform agenda adopted by the Lisbon European Council in 2000 and reaffirmed by the Stockholm European Council in 2001.

\subsection{Potential Welfare Gains of Financial Integration in the EU}

In the late 1980s, the EC Commission, the executive body of the EU, tasked a research team to estimate the economic benefits of a completed single market. Many independent economic experts, consultants, and research institutions contributed to this project, with support from the EC Commission's departments. One aim of this project was to quantify the reduction in the cost of financial services associated with financial integration in the $\mathrm{EC}$ and the impact that this could have on the economy as a whole.

The team estimated the prices of a series of representative financial products before and after the abolition of legislative barriers, particularly exchange controls. Their analysis was based entirely on the measures of the Internal Market Program, and therefore it did not assume a common currency.

Their main findings can be summarized as follows:

- Potential price reductions in financial services for the eight EC countries examined would be as high as 10 per cent, on average, implying a permanent cost reduction for the economy of about 0.7 per cent of GDP.

- The extent of the price reduction would vary substantially between countries. The sharpest fall was expected for Spain (21 per cent), followed by Italy, France, Belgium, and Germany (with 14, 12, 11, and 10 per cent, respectively), while Luxembourg, the United Kingdom, and the Netherlands would appear in the lowest category (with 8,7 , and 4 per cent, respectively).

These differences in price-reduction potential were attributed to discrepancies between the countries in terms of economic structure, competition, and regulatory environment. 


\section{Data Collection}

For the purpose of this paper we have collected the data of $15 \mathrm{EU}$ member countries from World Bank Development Indicators database. We have analyzed the data 5 years before the EURO introduction and 5 years after performance 1999. Basically we have checked whether the EURO introduction really improved member countries economies and trade or not.

\section{Data Analysis}

\subsection{Steady Growth in Member Countries (Figure 1 and 2)}

A single currency should end currency instability in the participating countries (by irrevocably fixing exchange rates) and reduce it outside them. Because the Euro would have the enhanced credibility of being used in a large currency zone, it would be more stable against speculation than any individual currencies. An end to internal currency instability and a reduction of external currency instability would enable exporters to project future markets with greater certainty. This will unleash a greater potential for growth.

\subsection{Increased Trade in Member Countries (Figure 3 and 4)}

Currency unions are generally formed as part of a larger strategic push to integrate the countries entering the currency union, often in combination with free trade agreements, harmonization of legal standards, and liberalized migration laws. A currency union seems certain to reduce the transaction costs incurred now by traders and travelers which motivate more trades between countries and traveling.

Businesses would no longer have to pay hedging costs which they do to minimize their exposure against currencies. Businesses, involved in commercial transactions in different member states, would no longer have to face administrative costs of accounting for the changes of currencies, plus the time involved.

From the graph also we can see assuming the mid point as 1999 (the introduction of EURO currency union), the trades are having steady growth in the member countries after 1999 where before 1999 in some countries the trades were stable or having very less growth.

\subsection{Reduced Real Interest in the Member Countries (Figure 5)}

Another interesting factor is before 1999 meaning before introduction of EURO, the real interest was very different in different countries. But introduction of currency union bring the interest rates into a range. Based on the graph below, we can come to this conclusion that currency union can stabilize the interest rate and decrease the inflation factors.

\subsection{Regional Average Growth (Figure 6)}

As we know that all the member countries had different characteristics in terms of their economy prior joining to the EURO platform. But after the introduction of EURO, from the graph we can see that the member countries are having regional average growth, meaning the higher growth countries are starting to have low growth and the low growth countries are having higher growth rate. And the trend started showing a range of average growth for the past few years. It may happen due to higher number of trades and free trade agreements.

\section{Conclusion}

As we see currency union is meant for regional growth. This union does not really improve one countries performance but also increase the overall regional growth. It increases co-operation between countries in terms of trades, monetary policy etc. But the question may come in a way that - how about other regions, why they don't join or organize new currency unions. But the situation is, for example, among the Muslim countries the vast difference in terms of the economic performances. It means some Muslim countries are having very poor economic performance and on the other hand some are in the other extreme. But still since the currency union is meant for regional growth, it will be a good step to go for it to improve the economic performance of the lowest extremes. May be the current phenomena in the Muslim world to have "Gold Dinar" is a good option for it.

\section{References}

Andrew K. Rose. (2000). Currency Unions and International Integration. [Online] Available: www.nber.org/paper/w7872, Retrieved Date: February 15, 2008

Anwar, M. (2002). Euro and Gold Dinar: A Comparative Study of Currency Unions Proceedings of the 2002 International Conference on Stable and Just Global Monetary System International Islamic University Malaysia, Page 361-381 
Bacha, O. (2007). A common currency area for ASEAN? Issues and feasibility Applied Economics, Published By: Routledge, ISSN: 0003-6846, Page 515-529.

Basevi, Giorgio, Michele Fratianni, and others. (1978). "The All Saints' Day Manifesto and its Critics" in One Money for Europe by Michele Fratianni and Theo Peeters. London: Macmillan Press Ltd., Page 39.

Caravelis, Georges. (1994). European Monetary Union: An application of the fundamental principles of monetary theory, Published By: Aldershot: Avebury, Page 23

Eichengreen, Barry and Jeffry Frieden. (2001). "The political economy of European Monetary Unification: an Analytical Introduction" in The Political Economy of European Monetary Unification by Barry Eichengreen and Jeffry A. Frieden (eds.), Boulder, Colorado, USA: Westview Press, Page 7

European Commission. (1995). One Currency for Europe: Green Paper on the Practical, Arrangements for the Introduction of the Single Currency, Office for Official Publications of the European Communities, Luxembourg.

Expert Group on the Changeover to the Single Currency. (1995). Progress Report on the Preparation of the Changeover to the Single European Currency. Submitted to the European Commission on May 10, 1995, Compiled by the Expert Group on the changeover to the single currency, Office for Official Publications of the European Communities, Luxembourg.

Gros Daniel and Niels Thygesen. (1992). European Monetary Integration: From the European Monetary System to European Monetary Union. London: Longman, Page 4

Klein, Benjamin. (1978). Competing Monies, European Monetary Union and the Dollar in One Money for Europe by Michele Fratianni and Theo Peeters, Published By: Macmillan Press Ltd., Page 84

Lehment, Harmen. (1984). "Freely Flexible Exchange Rates or a Common Currency? A New Look at the Issue" in Currency Competition and Monetary Union by Pascal Salin (ed.) Hague: Martinus Nijhoff Publishers, Page 248-249

Liliane karlinger. (2002). The Impact of Common Currencies on Financial Markets: A Literature Review and Evidence from the Euro Area, Bank of Canada Working Paper Series, [Online] Available: www.bankofcanada.ca/en/res/wp/2002/wp02-35.pdf, Retrieved Date: May 17, 2008

Meera, Ahamed K. M. (2002). The Islamic Gold Dinar, Subang Jaya, Selangor, Malaysia: Pelanduk Publications, Page 79-87

Owen, Deborah and Peter Cole. (1999). EMU in Perspective: Understanding Monetary Union. London: Prentice Hall, Page 6

Raymond, R. (1995). Scenarios for a Single Currency and EMU - The European Perspective, Proceedings of the European Movement Conference, Davenport Hotel, June 21, European Movement, Dublin.

The Merger Treaty of 1967 combined the three existing communities: ECSC, EEC, and EURATOM. The term European Community (EC) came into use following this Treaty. [Online] Available: en.wikipedia.org/wiki/European_Communities, (May 31, 2010)

Triffin, Robert. (1980). The Relationship Between the International Monetary System and Regional Monetary Systems in Arab Monetary Integration: Issues and Prerequisites by Khair El-din Haseeb and Samir Makdisi (eds.) London: Croom Helm, Page 39-59

Table 1. Fixed Euro Conversion Rates

\begin{tabular}{|l|l|}
\hline 1 euro(as of 1/1/07) & $=40.3399$ Belgian Franc \\
& $=1.95583$ German Mark \\
& $=166.386$ Spanish Peseta \\
& $=6.55957$ French Franc \\
& $=340.750$ Greek Drachma \\
& $=0.787564$ Irish Pound \\
& $=1,936.27$ Italian Lira \\
& $=40.3399$ Luxembourg Franc \\
& $=2.20371$ Dutch Guilder \\
& $=13.7603$ Austrian Schilling \\
& $=200.482$ Portuguese Escudo \\
& $=5.94573$ Finnish Markka \\
& $=239.640$ Slovenian Tolar \\
\hline
\end{tabular}




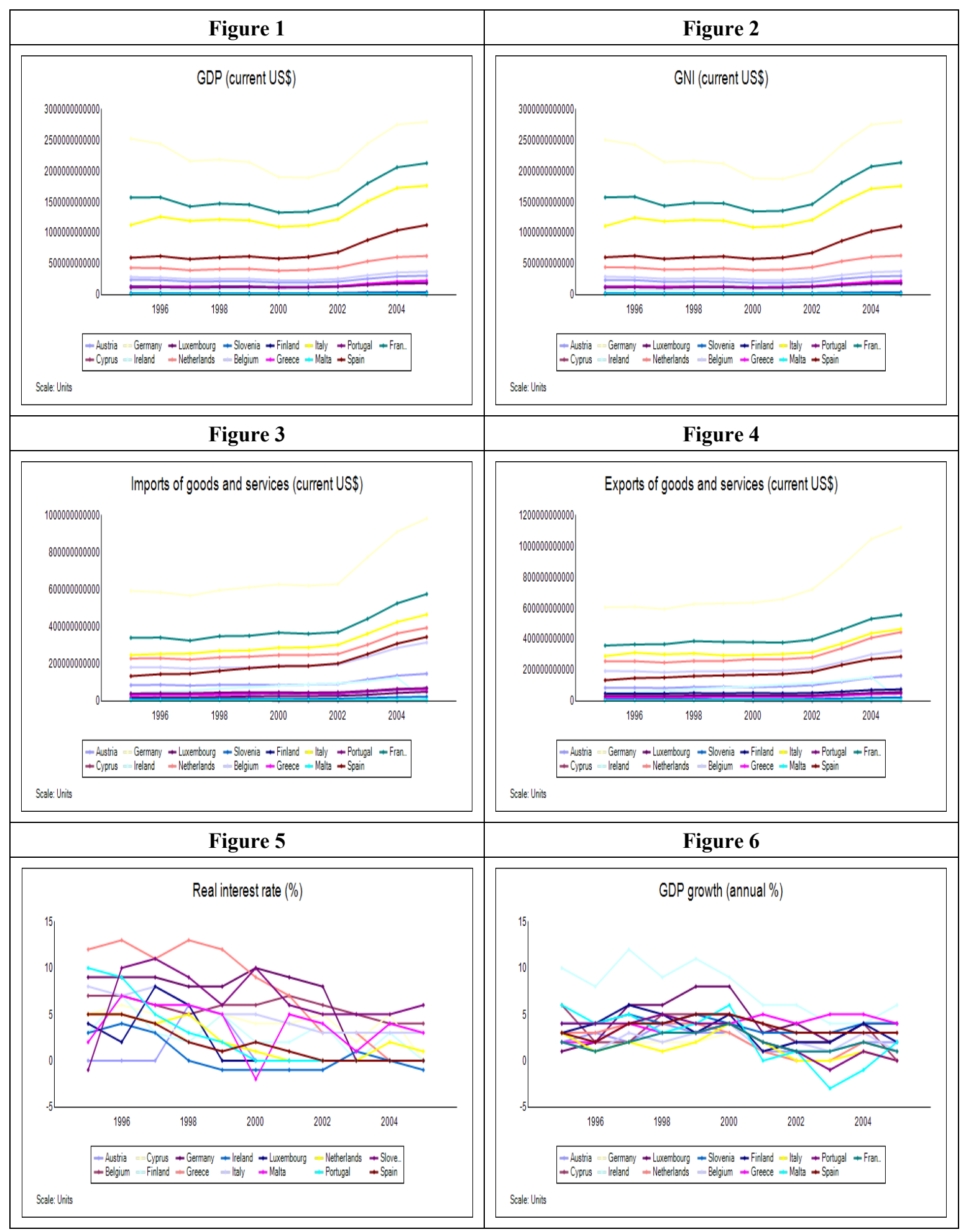

